\title{
UNDER THE SIGN OF AN EVIL POWER: JACOB BURCKHARDT AND ALFREDO BOSI
}

\author{
Robert Patrick Newcomb \\ University of California-Davis
}

For those interested in comparative approaches to the work of Brazilian literary and cultural critic Alfredo Bosi (b. 1936) - the wide-ranging author of $O$ ser e o tempo da poesia (1977) and Dialética da colonização (1992), among many other studies - the Swiss cultural historian Jacob Burckhardt (1818-1897) certainly does not represent an immediately intuitive pairing. Likewise, it can safely be assumed that very few Burckhardt scholars have heard of Bosi, whose reception beyond Brazil is largely circumscribed to Lusophone and Latin American-studies circles. Superficially at least, Bosi and Burckhardt are very different: Bosi has dedicated the bulk of his critical production to analyzing how literary discourse and popular culture alike work in colonial and neocolonial contexts to resist structures of power. By contrast, Burckhardt, writing from the bucolic remove of Basel, Switzerland, assiduously defended a "high" European culture he saw as threatened by both grasping politicians and unwashed masses. Burckhardt, a self-described (though quite heterodox) conservative, had little regard for popular culture and for non-European peoples, declaring in his Judgements on History and Historians (posthumously published, 1929) that, "only the civilized [i.e. Greco-Roman and then European] nations, not the primitive ones, are part of history in a higher sense" (Judgements, 1). Despite differences in back story, ideology, and critical focus, the BosiBurckhardt comparison proves fruitful for those interested in the broad, conflicted relationship between power and cultural production, and in particular, for those concerned with the contradiction apparent in culture's simultaneous position as the product and assumed critic of power.

I will organize my present analysis around Burckhardt's formulation and Bosi's reception of the idea that "power is in itself evil" (die Macht an sich böse ist), which Burckhardt 


\section{Robert Patrick Newcomb}

repeated as a kind of mantra throughout his historiographical reflections. In the first section I will sketch out Burckhardt's bifurcated vision of power, focusing on his distinction between power viewed in moral terms (and condemned as categorically "evil"), and power considered as a constructive historical force, as a necessary albeit morally dubious precondition for the rise of civilization and therefore, for the creation of culture, which the Swiss historian broadly identified with "the good." In the second section I will shift focus to Bosi's view of culture as embodied resistance, arguing that Burckhardt's vision of power as "evil" works to lend coherence to Bosi's simultaneous insistence on culture's embeddedness within (and indebtedness to) socio-historical power structures, and his affirmation of the critic's ethical obligation to resist these same structures.

\section{From Burckhardt to Bosi}

One of the very few written references Bosi makes to Burckhardt comes in the opening pages of Dialética da colonização, in the suggestively titled chapter "Colônia, Culto e Cultura." Here Bosi refers to Burckhardt's "palavras agonísticas" on the nature of power and quotes the latter's Reflections on Universal History. Bosi's reference to Burckhardt occurs during a discussion of culture's capacity and obligation to resist colonial and neocolonial power structures:

Uma certa ótica, que tende ao reducionismo, julga de modo estrito o vínculo que as superestruturas mantêm com a esfera econômico-política. É preciso lembrar, porém, que alguns traços formadores da cultura moderna (traços mais evidentes a partir da Ilustração) conferem à ciência, às artes e à filosofia um caráter de resistência, ou a possibilidade de resistência, às pressões estruturais dominantes em cada contexto. Nas palavras agonísticas do historiador Jakob Burckhardt, para quem o poder é em si maligno,

a cultura exerce uma ação constantemente modificadora e desagregadora sobre as duas instituições sociais estáveis [Estado e Igreja - o texto é dos meados do século XIX], exceto nos casos em que estas já a tenham subjugado e circunscrito de todo a seus próprios fins. Mas quando assim não se dá, a cultura constitui a crítica de ambas, o relógio 
que bate a hora em que forma e substância já não mais coincidem.

Esse vetor da cultura como consciência de um presente minado por graves desequilíbrios é o momento que preside à criação de alternativas para um futuro de algum modo novo. Em outro contexto ideológico Antonio Gramsci propôs a crítica do senso comum e a consciência da historicidade da própria visão do mundo como pré-requisitos de uma nova ordem cultural (Dialética, 17; author's emphasis and ellipsis)

This is Bosi's only reference to Burckhardt in Dialética da colonização, and indeed the only mention I could find in any of Bosi's major critical texts. It is safe to say, then, that Burckhardt does not feature alongside Otto Maria Carpeaux and Benedetto Croce as one of Bosi's recurring points of theoretical reference. Bosi confirmed this absence at an 8 October 2008 symposium at Princeton University, in which he replied to my question on Burckhardt's possible influence that "[e]videntemente [Burckhardt] não foi autor de cabeceira" during Bosi's formative years, nor during the composition of Dialética. Though significantly, Bosi did acknowledge "afinidades eletivas com ele," and affirmed his belief in Burckhardt's judgment concerning power's intrinsically evil character, though he qualified the idea as "idealista." Bosi explained that he had been led to Burckhardt and especially his book The Civilization of the Renaissance in Italy (1860) by way of the Austro-Brazilian critic Carpeaux. ${ }^{1}$ Bosi confirms his approximation to Burckhardt via Carpeaux in an unpublished 4 June 2008 interview with Breno Longhi. In the interview Bosi mentions the Burckhardt-themed essays that bookend Carpeaux's volume A cinza do purgatório $(1942)^{2}$ and emphasizes the relevance of Burckhardt's critical stance toward worldly power for Carpeaux as an Austrian Jew recently exiled to Brazil by Nazism (Interview, 5). In explaining Carpeaux's role as an intellectual intermediary between Burckhardt and Bosi, it is worth citing the

1 For Carpeaux's general influence, see "Carpeaux e a dignidade das Letras" (Céu, 167-69).

2 These are "Jacob Burckhardt: Profeta da nossa época" and "Jacob Burckhardt e o futuro da inteligência." 
following passage from Carpeaux's "Jacob Burckhardt e o futuro da inteligência":

\begin{abstract}
"Todo poder é mau." Aqui está o centro da doutrina burckhardtiana, muito impregnada de Schopenhauer e do seu pessimismo anti-histórico, muito impregnada do fatalismo dos estóicos; [...] As obras da civilização necessitam de ordem, é verdade. Mas o estado florescente da arte, sob a ordem dos déspotas, não passa de uma razão atenuante, boa para fazer reaparecer os tempos longínquos, sob a luz de uma falsa transfiguração. "Uma ilusão de óptica nos engana sobre a felicidade em certas épocas, em relação a certos povos. Mas essas épocas eram também, para outros, épocas de destruição e de escravatura; tais épocas são consideradas felizes, porque não se leva em conta, et pour cause, a euforia dos vencedores." A felicidade não é senão uma ilusão de óptica dos historiadores (82-83; author's emphasis).
\end{abstract}

For Carpeaux, Burckhardt's key insight seems to be that civilization's achievements, facilitated by power, are illusory and should not distract the critic from the need for critical moral or ethical judgment, through which power must be condemned as a categorically evil force, regardless of its role as the motor of historical "progress"-which in light of World War II and the Holocaust must have appeared to Carpeaux as a particularly dubious concept. Indeed, in contextualizing Carpeaux's evaluation of Burckhardt, one should note that the horrors of the two World Wars led to a broad upward reappraisal of the Swiss historian in German intellectual circles, with Friedrich Meinecke and others casting Burckhardt as a mournful prophet of twentiethcentury totalitarianism. ${ }^{3}$

Bosi evidently inherited Burckhardt's elevation of denunciatory moral judgment to a position of parity with his observations concerning power as a constructive historical force. Bosi writes on the importance for the writer, in this case the nineteenth-century Brazilian novelist Raúl Pompéia, of "descobri[r] na metaforização do poder uma crítica radical e uma pulsão de revolta que tem ganas de incendiar, pela virulência da palavra, a pólis insofrível" (Céu, 46). However,

\footnotetext{
${ }^{3}$ For example, see Meinecke's The German Catastrophe (1946).
} 
the general tone of Bosi's argument on the power/culture relationship is markedly more optimistic that Burckhardt. Bosi describes himself in Dialética da colonização as witnessing, for instance, a period of "renascimento latinoamericano e afro-antilhano." Burckhardt would have never judged his own late nineteenth century present so favorably (Dialética, 63).

In any case, Burckhardt's - and I would argue Bosi'srecognition of power's simultaneously (and perhaps contradictorily) moral and historical aspects, which work on each other in dialectical fashion, is what separates the Swiss historian's clear-headed commitment to introduce ethical judgment into historical observation from a reductive or simplistic moralism (Dialética, 130). Friedrich Nietzsche, Burckhardt's junior colleague at the University of Basel, clarifies for us the relationship between these two dimensions in a September 1886 letter to Burckhardt:

I know nobody who shares with me as many prepossessions as you yourself; [...] The mysterious conditions of any growth in culture, that extremely dubious relation between what is called the "improvement" of man (or even "humanization") and the enlargement of the human type, [and] above all, the contradiction between every moral concept [Moralbegriff] and every scientific concept [wissenschaftlichen Begriff] of life (Selected Letters, 255; author's emphasis; Briefwechsel, 254).

From the point of view of the artist or critic, the problem concerns one's inevitable participation in the same power relations one should feel compelled to condemn. Bosi explains: "[S]e a arte é idealmente livre em relação à ordem social, a pessoa pública e histórica do artista evidentemente não o é, pois vive nela, e dela faz parte. Daí vem o dilaceramento entre a sua atividade criadora e o seu papel na máquina do sistema" (Céu, 56). Or piggybacking on Gramsci's insight: "Cada um de nós forma-se e age no interior de instituições, pois a cultura preexiste e sobrevive à ação do sujeito" (246). For Burckhardt, the inevitable indebtedness of cultural articulation to power obliges a certain skepticism regarding the value of a given historical period's assumed achievements - though the Swiss historian explains 


\section{Robert Patrick Newcomb}

his skepticism here with specific reference to power's intrinsically evil character and to possible bias on the part of the observer, rather than by means of the broader structural patterns Bosi favors. Bosi, more concerned with the concrete effects of coercive power on oppressed groups than with its essential moral value, proposes a more radical course for the critic, which he explains in his perceptive essay on Pompéia's novel $O$ Ateneu (1888): "Se a lógica do sistema é inapelável, a reação da consciência insubmissa deverá praticar as táticas de uma guerrilha que começa na mente" (47).

Burckhardt's bifurcated (and one must admit, somewhat ambivalent) view of power strikes me as one of the most compelling features of his vision of history. ${ }^{4}$ Burckhardt clarifies the specific implications for culture of his distinction between moral and historical approximations to power in his Reflections. Here he presents Culture (Kultur) as one of "three powers" whose continual interactions - and not some sort of pre-determined Weltplan-define the course of history. He explains:

Culture may be defined as the sum total of those mental developments which take place spontaneously and lay no claim to universal or compulsive authority [...] Its action on the two constants [that is, the two other powers, State and Church] is one of perpetual modification and disintegration, and is limited only by the extent to which they have pressed it into their service and included it within their aims [...] Otherwise it is the critic of both, the clock which tells the hour at which their form and substance no longer coincide (Force, 140).

Culture, despite its pretensions toward removal from the sphere of historical action (recall that for Burckhardt it "lay[s] no claim to universal or compulsive authority"), which would seem to promote its critical function, can easily be "pressed into [...] service" by the State and Church. That is, culture may perennially be co-opted by the same forces that created it in the first place. In other words, culture is a force simultaneously productive of and produced by history and is therefore solidly situated within structures of earthly

\footnotetext{
${ }^{4}$ On Burckhardt's ambivalence toward power, see Sigurdson, 424-25.
} 
power, even as it exercises a moralizing function that aspires to remove it from this sphere.

Returning to the paraphrase that opened this first section, here Bosi refers first to the burckhardtian phrase die Macht an sich böse ist, repeated throughout the Swiss historian's Judgements and likewise posthumous Reflections on Universal History (1905) as a sort of declaration of his faith that power (Macht) will persist as "part of the great economy of world history [grossen weltgeschichtlichen Oekonomie]," or to employ Gregório de Matos's metaphor, the "máquina mercante" of the world (Force, 361; Weltgeschichtliche, 382). The corollary to Burckhardt's implicitly anti-Enlightenment idea on the non-extinguishability of evil is his opinion that human capacities - among them, humankind's degree of predilection toward evil actions - remain constant as historical time advances. Indeed, Burckhardt believed that the meaning of the "good" (which he enthusiastically associated with Kultur), was only intelligible due to the persistence of evil in the world as its opposing term, thus rendering senseless and futile any and all human attempts to rid the world of evil. He explains: "[E]vil, as ruler, is of supreme importance; it is the one condition of selfless good" (Force, 362-63). ${ }^{5}$ Burckhardt draws on the idea of power's necessarily evil character (an idea he incidentally takes, at least in terms of his phraseology, from Johann Georg Schlosser [1739-1799]) to condemn - or in Bosi's words, "cha$\mathrm{ma}[\mathrm{r}]$ pelo nome vero"-various figures or even entire historical periods (Céu, 107). Though he admits on another occasion that this sort of historical judgment is necessarily influenced by "the prejudices of our egoism" (Judgements, 31). For example, Burckhardt refers to the idea of a necessarily evil power and to "the privilege of egoism" or lust for power (machtgierig) as its corollary at the level of individual

\footnotetext{
5 "Morality as a power [...] stands no higher, nor is there more of it, than in so-called barbarous times" (Force, 149). One of Burckhardt's principal targets was what he identified as Enlightenment philosophy's "great optimistic will" and idealism's faith in the essential "goodness of human nature," which for Burckhardt was in fact "a mixture of good and evil." (Judgements, 252; author's emphasis).
} 
behavior, in explaining the justifications given by the Power State (Machtstaat) for its inevitable expansionist tendencies (Force, 115; Weltgeschichtliche, 224). ${ }^{6}$ Burckhardt's repeated denunciations of Bismarckian militarism show us that for him, power is intimately connected with the individual ego, and once again, is simultaneously destructive (and therefore condemnable) and constructive (ergo necessary).

Bosi's analysis, like Burckhardt, is also marked by the specter of aggressive expansionism, though in his case the culprit is not the militarized state per se but the capitalistic/ imperialistic system of which the state is just one manifestation along with the ideology that is both product and bulwark of the system. ${ }^{7}$ Notwithstanding Bosi's emphasis on the colonizer's expansionist impulses as part of a larger process (and "processo colonizador" is precisely the term he employs here) and his rather neutral definition of power as a "formação econômico-social" in the first chapter of Dialética da colonização, one notes more than a few traces in Bosi of the same passionate denunciation and moralizing preoccupation apparent in Burckhardt, and specifically in Bosi's discussions of individual lust for power (Dialética, 19, 23). See, for example, Bosi's description of Iberian colonization of the New World as motivated by greed (cobiça) and by a generalized "ímpeto predatório e mercantil" (20). This description would have resonated with Burckhardt, who described Spanish colonization in strikingly similar terms as impelled by "the mere greed for gold," and as a dramatic encounter between power Macht and Geld (Judgements, 107; Historische, 117). Burckhardt explains on another occasion that "[f]irst and foremost [...] what the nation desires, implicitly or explicitly, is power," and opines that,

\footnotetext{
${ }^{6}$ On the Machtstaat, which Burckhardt frequently identified with the Prussian-dominated German Empire, see Meinecke, "Ranke and Burckhardt," 149-50.

${ }^{7}$ For ideology in Bosi: "[A] partir do século XIX, [...] o estilo capitalista e burguês de viver, pensar e dizer se expande ao ponto de dominar a Terra inteira. O Imperialismo tem construído uma série de esquemas ideológicos de que as correntes nacionalistas ou cosmopolitas, humanistas ou tecnocráticas, são momentos diversos, mas quase sempre integráveis na lógica do sistema" (O ser e o tempo, 164).
} 
"power is of its nature evil, whoever wields it. It is not stability but a lust [Gier], and ipso facto insatiable, therefore unhappy [unglücklich] in itself and doomed to make others unhappy" (Force, 183-84; author's emphasis; Weltgeschichtliche 166). Even if we accept power's historical necessity, for Burckhardt and Bosi alike it retains its "unhappy" character for the individual (whether he wields power or is subject to it), along with its ultimate moral dubiousness. Summarizing the problem:

[F]rom the fact that good came of evil, and relative happiness of misery, we cannot in any way deduce that evil and misery were not, at the outset, what they were. Every successful act of violence is evil, and at the very least a dangerous example. But when that act was the foundation of power, it was followed by the indefatigable efforts of men to turn mere power [Macht] into law and order. With their healthy strength [Kräfte], they set to work to cure the State of violence (Force, 362; Weltgeschichtliche, 384).

Burckhardt recognized that, while in ethical terms power must be condemned, and notwithstanding its corrupting effects on the individual (Burckhardt's opinion appears as a more radical version of Lord Acton's famous maxim), power's exercise is necessary for social and cultural construction, and by extension, for the continuity of history. This is clarified in Burckhardt's comments on state formation. While he declares categorically that "[n]o good results can exculpate an evil past" - and indeed he views the State, from Rome to unified Germany, as inevitably founded on crimehe nonetheless judges that, "men must come to terms even with the greatest horrors [...]; they must rally such sound strength [Kräfte] as is left in them, and go on building" (Force, 116; Weltgeschichtliche, 85). That said, Burckhardt denounces as unforgivably self-interested the instrumental, or as he mockingly terms it, the "progressive" approach to history in which the historian justifies past horrors because they created the conditions which allow him to view the past as one of history's so-called winners:

"This or that hallway would have to be the most beautiful if only because it leads to our room." What coldness and heartlessness 


\section{Robert Patrick Newcomb}

there is in this attitude, the ignoring of the silenced moans of all the vanquished, who, as a rule, had wanted nothing else but parta tueri [to preserve what had come into being]. How much must perish so that something new may arise!" (Judgements, 85; author's emphasis).

My elision of the term "progress" in characterizing Burckhardt's position is deliberate. He repeatedly rejected the idea as infected with misplaced Enlightenment optimism, and found "supremely ridiculous" the notion that his own late nineteenth century constituted an "age of moral progress." Recall that he viewed humanity's moral potential as fixed, and relatively low at that (Force, 149).

Here Bosi's position once again dovetails with Burckhardt. Bosi, in historicizing the idea of progress and proposing it as a feature of the colonial process, effectively questions its self-standing ontological value: "Se o aumento na circulação de mercadorias se traduz em progresso, não resta dúvida de que a colonização do Novo Mundo atuou como um agente modernizador" (Dialética, 20; author's emphasis). And Bosi's vision of state (and colony) formation is similarly marked by a condemnable though perhaps inevitable violence: "Contraditória e necessariamente, a expansão moderna do capital comercial, assanhada com a oportunidade de ganhar novos espaços, brutaliza e faz retroceder a formas cruentas o cotidiano vivido pelos dominados" (21). While Burckhardt's focus on the Machtstaat and his broad suspicion of systematic historiographical approaches (he repeatedly critiques Hegel and "the philosophy of history") precludes him from contextualizing power within a broadly materialistic array of socio-economic forces, as does Bosi, he at least suggests the idea of historical systematicity in his passing references to the "great economy of world history [grossen weltgeschichtlichen Oekonomie]," and to a "concealed supreme power [verborgene höchste Kraft]" that apparently moves history forward - albeit toward an undesirable future of increasingly efficient State-commercial coercion which Bosi terms in another context, "essa barbárie nova em que se aliaram o poder pelo poder e a técnica mais avançada" (Force, 80, 361; Weltgeschichtliche, 382; 
Judgements, 175; Historische, 194; Céu, 203). Though significantly, the forces that Burckhardt would see maintained in rough equilibrium are moral as opposed to material: "Good and evil, perhaps even fortune [Glück] and misfortune [Unglück], may have kept a roughly even balance throughout all the various epochs and cultures" (Force, 149; Weltgeschichtliche, 124). This would guarantee at least the possibility of high culture's continuity, though Burckhardt predictably tempers this apparently reassuring appraisal in his repeated, glum warnings of the predations of opportunistic politicians and the culturally deaf masses: "Philistinism and force have always existed side by side with culture, and we must [therefore] always be on our guard against optical illusions in appraising spiritual greatness in its own time" (146). While Bosi's writings, and in particular his writings on colonialism, are strongly informed by an impulse toward moral judgment, the Brazilian critic seems to conceive of the ethical rather differently than Burckhardt, and his vision of culture as resistance opens, I would argue, a broad space for popular participation in the debate on power and culture. This offers a welcome corrective to Burckhardt's shortsighted foreclosure of all but the most elite forms of cultural expression, which he further circumscribes to the European center. I will explore Bosi's thoughts on this issue in the following paragraphs, attempting further to demonstrate how Burckhardt's vision of a bifurcated though fundamentally "evil" power can be seen as productively informing Bosi's work on culture as resistance, and indeed, is advanced by Bosi's work.

\section{From Bosi back to Burckhardt}

One of the most salient differences between Bosi and Burckhardt concerns their divergent treatments of the colonial context, of colonial/metropolitan relations, and of colonization as a phenomenon. This not atypical problem is raised by almost any comparative attempt to counterpose an intellectual paradigm articulated from the standpoint of the colony or ex-colony and centered on the colonial experience (in this case Bosi), with one developed in the metropole, 


\section{Robert Patrick Newcomb}

which presents the European and North American experience as normative, and which is largely unconcerned with colonial issues (here Burckhardt). Bosi elevates the idea of the colony and its varying iterations (colonization, colonialism, and post-colonialism) to the center of his analysis of power, especially in Dialética da colonização and Literatura e resistência (2002), largely focusing on Luso-Brazilian literary and historical examples and presenting a model of historical development as essentially guided by imperialism, of which colonialism constitutes one manifestation. He explains: "O Imperialismo tem construído uma série de esquemas ideológicos de que as correntes nacionalistas ou cosmopolitas, humanistas ou tecnocráticas, são momentos diversos, mas quase sempre integráveis na lógica do sistema. Nós vivemos essa 'lógica' e nos debatemos no meio das propostas que ela faz" (O ser e o tempo, 164).

In contrast to Bosi, who presents the colony as normative, Burckhardt's references to colonialism are few and uniformly unsympathetic - curious given his elegiac comments on other (European) victims of historical violence. In introducing his concept of the State in his Reflections, Burckhardt limits himself to a minimal reference to "colonial possessions and the difference between mere trade dominion and genuine colonial empire" (Force, 113). Shortly thereafter he considers "whether civilization really penetrates below the surface of barbarism and what good can come of the posterity of conquering peoples and conquered barbarians, especially when they are of different race, whether it is not better for them to retire and die out (as in America), and whether the civilized human being flourishes everywhere on the alien soil" (117). Moreover, in his Judgements Burckhardt resoundingly affirms Europe's historical centrality as "a place where the richest formations originate, a home of all contrasts which dissolve into the one unity that here everything intellectual is given voice and expression" (173). While at least one commentator (the Mexican humanist Alfonso Reyes) presents Burckhardt's mention of the importance of historical "hybrids" as shading toward a valorization of racial and civilizational cross-fertilization, this interpretation 
seems forced. ${ }^{8}$ In Burckhardt's brief reference to hybridity in his Reflections, he refers to intellectual exchange and eclecticism rather than to the sort of cultural and affective contact that would perhaps result in a multiracial society of the type idealized by various Latin American intellectuals of Reyes's generation (including José Vasconcelos and Gilberto Freyre). And Burckhardt's comments elsewhere show him little sympathetic to all but the most lily-white of societies. If we are to productively apply Burckhardt's compelling ideas on power to a colonial context which he thoroughly ignores, we must look outside his texts for a corrective, a need that underscores Bosi's particular relevance.

As I suggested earlier, Bosi presents colonialism as part of a "processo totalizante" aimed at resolving civilizations' "tensões internas" through outward-looking attempts at conquest and/or settlement of foreign lands. This colonialism-impelled "chamado processo civilizatório" comprehends not only the frequently violent formation and consolidation of political units (kingdoms, empires, etc.) and the rise of exploitative systems of production and distribution (mercantilism followed by nascent and late capitalism), but moreover entails the production of culture (both "high" and popular, hegemonic, resistant, and ambivalent) (Dialética, $12-13,18)$. One notes a tension in Bosi's analysis that is quite reminiscent of that confronted by Burckhardt in his Considerations and Judgements. This concerns the question of reconciling the discrepancy between power viewed in moral terms as unforgivably coercive, and power considered as productive of culture, which for Bosi as for Burckhardt holds out at least the possibility of embodying what could broadly be identified as "the good." In Bosi's case, the deleterious effects of power take on a form appropriate to the colonial Brazilian context and to the author's broadly materialistic and much less statist (that is, relative to Burckhardt) view of history and of cultural production. Bosi identifies the

\footnotetext{
${ }^{8}$ See Reyes's "Prólogo a Burckhardt," which he wrote for a Spanish translation of Burckhardt's Reflections (México: Fondo de Cultura Económica, 1943).
} 


\section{Robert Patrick Newcomb}

dark side of power with the horrors of slavery, with the extermination of indigenous populations, and with patterns of economic exploitation by local and foreign elites-in sum, with a full range of tensions, crimes, and inequalities resulting from colonialism as an overarching process - rather than with the specific threat of militaristic expansion by the Machtstaat. ${ }^{9}$ As Bosi explains in "Céu, inferno," his eloquent essay on Graciliano Ramos and João Guimarães Rosa:

Sem dúvida, o capital não tem pátria, e é esta uma das suas vantagens universais que o fazem tão ativo e irradiante. Mas o trabalho que ele explora tem mãe, tem pai, tem mulher e filhos, tem língua e costumes, tem música e religião. Tem uma fisionomia humana que dura enquanto pode. E como pode, já que a sua situação de raiz é sempre a de falta e dependência" (Céu, 10).

For Bosi, the humanity of the poor and the oppressed manifests itself in terms of cultural production in a posture of resistance toward power, this being a concept much developed by Bosi in essays like "Poesia-resistência," from $\mathrm{O}$ ser e o tempo da poesia (1977), and "Literatura e resistência," included in the volume of the same name. Resistance appears in Bosi's work as a theme for literary or cultural expression, and perhaps more importantly as a process inherent to forms of everyday, popular culture that often operate, as he puts it, "sob o limiar da escrita" (Literatura, 120; Dialética, 46). Resistance as a literary or artistic practice may manifest itself in erudite works that (consciously or unconsciously) critique or oppose themselves to the same conditions of power that allow for their consecration. This results in texts that, in addition to serving the important political function of articulating oppositional programs,

\footnotetext{
${ }^{9}$ For colonialism as a totalizing process in Bosi, see the following: "[N]ão há condição colonial sem um enlace de trabalhos, de cultos, de ideologias e de culturas" (Dialética, 377). And for the connection between colonization in Latin America and the development of European capitalism: "Se o aumento na circulação de mercadorias se traduz em progresso, não resta dúvida de que a colonização do Novo Mundo atuou como um agente modernizador da rede comercial européia durante os séculos XVI, XVII e XVIII. Nesse contexto, a economia colonial foi efeito e estímulo dos mercados metropolitanos na longa fase que medeia entre a agonia do feudalismo e o surto da Revolução Industrial" (20; author's emphasis).
} 
benefit aesthetically from their internal ideological tensions. In addition to enriching the text, Bosi judges that "[a] boa literatura é resistência em vários níveis" and regularly favors ideologically conflicted writers like Padre Antônio Vieira and Euclides da Cunha. This tension takes the form of an evident ambivalence toward power of the sort noted in Burckhardt. If it were not for the basic irony that power is both necessarily evil and necessarily constructive, the conditions would not exist for texts to be written that eloquently rail against the same power that brings them into being (Céu, 169).

Crucially, what allows a certain text (or ballad, or film, or performed cultural practice) to function for Bosi as resistance is the ethical preoccupation of its author and/or interlocutors, which inspires a questioning of the discrepancy between power viewed in moral and in historical-constructive terms. Here Bosi is the clear inheritor of the ethical preoccupation we see in Burckhardt, and of Burckhardt's bifurcated view of power. As Bosi considers in "Literatura e resistência," "[a] escrita resistente [...] decorre de um a priori ético, um sentimento do bem e do mal, uma intuição do verdadeiro e do falso, que já se pôs em tensão com o estilo e a mentalidade dominantes" (Literatura, 130; author's emphasis). Bosi clarifies that the impulse toward ethical judgment, which he appears to view as intuitive though only fully realized through a break with "false consciousness" and a subsequent commitment to oppositional political engagement, does not serve to liberate the novelist (or historian, or critic) from power as a concrete historical force. As Bosi notes, drawing on the example of Gramsci, "[a] inteligência, quando não mediada pela praxis, deságua no idealismo" (Céu, 241; author's emphasis). In passing, I would observe that if Burckhardt admittedly did not dedicate himself to oppositional activity to the same dramatic degree as the author of the Prison Notebooks, his self-conception as a political and intellectual rebel who insistently and repeatedly rejected both German nationalism of the Prussian-militaristic stripe and the idealist philosophy and triumphalist Rankian historiography that accompanied them, comfortably approxi- 


\section{Robert Patrick Newcomb}

mates him to Bosi's description of the oppositional intellectual possessed of an "ethical a priori."

Focusing specifically on narrative, Bosi explains that "[a] resistência é um movimento interno ao foco narrativo, uma luz que ilumina o nó inextricável que ata o sujeito ao seu contexto existencial e histórico. Momento negativo de um processo dialético no qual o sujeito [...] dá um salto para uma posição de distância e, deste ângulo, se vê a si mesmo e reconhece e põe em crise os laços apertados que o prendem à teia das instituições" (Literatura, 134; my emphasis). In other words, while the ethical impulse as manifested in rebellious literary discourse may speak to the author's aspiration to remove himself from the constraints imposed by his contextual situatedness (which would allow him to pass moral judgment from a comfortable position of exteriority), he and the broader idea of culture both remain inevitably grounded in this same context, here identified by Bosi with a "web of institutions." For all of Burckhardt's insistence on the importance of moral judgment and his attempts to elevate culture to the status of a transcendent good, he recognizes that the critic passes judgment while subject to a variety of historical, material, and other forces, and that culture is similarly grounded in the workings of worldy powerthough he acknowledges its striving toward removal:

Our reflections, properly understood, need do no violence to the true, the good, the beautiful. The true and the good are in manifold ways colored and conditioned by time; even conscience, for instance, is conditioned by time; but devotion to the true and the good in their temporal form, especially when it involves danger and self-sacrifice, is splendid in the absolute sense (Force, 87).

Indeed, in one musing from his Judgements, Burckhardt presents humans as constitutively incapable of resolving the contradiction between idealized exterior judgment and their contextual situatedness, which amounts to a variation on the conflict between power viewed morally and in concrete historical terms: "[W]e ought to live constantly in the intuition of the world as a whole. But this would require a superhuman intelligence that would be above temporal succession and spatial limitation, and yet in constant contemplative 
communion with it, and, on top of that, in sympathy with it" (178; my emphasis). With typical severity, Burckhardt maintains that the impossibility of this task does not permit the critical historian to abrogate his responsibility to try to square the circle:

As far as he is personally concerned, a historian may not be able to separate himself from the struggle of his locality. As a man existing in time he must desire and represent some definite thing, but as an historian he must maintain a loftier view (182).

As we have seen, Bosi takes a different tack, calling on the individual to respond to this contradiction not through a selfflagellating commitment to historiographical rigor, but through a socially-minded and courageous posture of resistance before the structures of power that, for him, bring about the contradiction in the first place. For Bosi, poetry is imbued - similarly but not identically to prose - with a capacity for resistance, with the poet like the novelist invariably finding herself subject to an unjust power to which she may acquiesce, or which she may resist, for instance, through a lyrical attempt at a "recuperação do sentido comunitário perdido," or by "crítica direta ou velada da desordem estabelecida," as in Gregório de Matos's satirical poetry (O ser e o tempo, 167). It is in these terms that Bosi reads Camões's Lusíadas in Dialética da colonização not as a triumphant commemoration of the glory of the Portuguese navigators, but as a highly ambivalent text that questions - namely in the Velho do Restelo's famous speech in Canto IV - the value of what the poet would denounce elsewhere as "a caduca e débil glória," particularly at the cost of so much human misery (Lírica, 279). The contrast between Bosi's interpretation of the Lusíadas and that offered rather unexpectedly by Burckhardt (who otherwise spends little time in his Reflections and Judgements on specifically Iberian topics) in one of his historical fragments is striking. For the Swiss historian, Camões serves as a national tribune. While for Burckhardt, "Camoens is not a poet for an entire civilized world, as was Homer," his epic is nonetheless "evenly permeated with the glory of Portugal and with patriotism" 
(Judgements, 147-48). If Burckhardt fails in his brief reflection to identify the ambivalence that is apparent in Camões's epic, he does recognize its potential as a national symbol, and utilizes his reading in order to return to one of his recurring qualms, that the modern "educated man" ("Gebildete") is incapable of appreciating true culture. Camões "expressed its [i.e. the nation's] feeling clearly and completely at a time which still tolerated true feeling" $(6,148)$.

In the preceding pages I have offered a comparative analysis of Alfredo Bosi and Jacob Burckhardt that looks to the Swiss historian's repeated proclamations on power's intrinsically evil character, and the bifurcated vision of power that follows, as its organizing principle. While Bosi and Burckhardt exist at a remove from each other in biographical and ideological terms, and while their historiographical and critical reflections are oriented rather differently (Bosi toward Brazilian erudite and popular cultural expression, Burckhardt toward exclusively "high" European culture), I have attempted to show that they share a broad concern with the conflicted nature of power, and with power's consequent implications for culture. Viewed side by side, Bosi and Burckhardt offer the contemporary critic a remarkable and perhaps surprising model for cultural analysis, one in which power works on culture, on its creators and its interpreters in manifold, contradictory ways, and one that makes available both persistent ethical preoccupation on the part of the writer-critic and a broad capacity for individuals across the socio-economic spectrum to participate in culture as resistance.

Works Cited:

Bosi, Alfredo. Céu, inferno. Ensaios de crítica literária e ideológica. São Paulo: Ática, 1988.

---. Dialética da colonização. 2a ed. São Paulo:

Companhia das Letras, 2002.

---. Interview on Otto Maria Carpeax. Interviewer:

Breno Longhi. 4 June 2008. Unpublished. 
---. Literatura e resistência. São Paulo:

Companhia das Letras, 2002.

---. O ser e o tempo da poesia. 6a ed. São Paulo:

Companhia das Letras, 2000.

Burckhardt, Jacob. Force and Freedom:

Reflections on History. Ed. James Hastings Nichols. Second Printing. New York: Pantheon Books, 1948.

---. Historische Fragmente. Aus dem Gesammelt von Emir Dürr mit einem vorwort von Werner Kaegi. Stuttgart: K.F. Koehler Verlag, 1957.

---. Judgements on History and Historians. Trans. Harry Zohn. London and New York: Routledge Classics, 2007.

---. Weltgeschichtliche Betrachtungen. Nach dem oerischen text herausgegeben von Werner Kaegi. Bern: Verlag Hallwag, 1947.

Camões, Luís de. Lírica. Belo Horizonte: Editoria Itatiaia, 1999.

Carpeaux, Otto Maria. Ensaios reunidos: 19421978. Org. Olavo de Carvalho. Rio de Janeiro: UniverCidade; Topbooks, 1999. v. I.

Meinecke, Friedrich. "Ranke and Burckhardt." German History: Some New German Views. Ed. Hans Kohn. London: George Allen \& Unwin Ltd., 1954. 141-56.

Nietzsche, Friedrich. Briefwechsel: krit. Gesamtausg. Nietzsche. Hrsg. von Giorgio Colli u. Mazzino Montinari. Berlin; New York: de Gruyter, 1982. v. III/3: Briefe von Friedrich Nietzsche: Januar 1885-Dezember 1886.

---. Selected Letters of Friedrich Nietzsche. Ed. and trans. Christopher Middleton. Chicago and London: The University of Chicago Press, 1969.

Sigurdson, Richard F. "Jacob Burckhardt: The Cultural Historian as Political Thinker." The Review of Politics, Vol. 52, No. 3 (Summer, 1990), 417-40. 